\title{
Effect of cardiopulmonary bypass on plasma digoxin concentrations
}

\author{
D. J. Coltart, D. A. Chamberlain ${ }^{1}$, M. R. Howard, M. G. Kettlewell, \\ J. L. Mercer, and T. W. Smith \\ From The Departments of Cardiology and Thoracic Surgery, St. Bartholomew's Hospital, \\ London, and Cardiac Unit, Medical Service, Massachusetts General Hospital, Boston, U.S.A.
}

Plasma digoxin concentrations were measured in II chronically digitalized patients during and after cardiac operation involving cardiopulmonary bypass. The mean concentration fell from $I \cdot 5 \mathrm{ng} / \mathrm{ml}\left(\mathrm{I} \mathrm{ng}=\mathrm{IO}^{-9} \mathrm{~g}\right)$ at induction of anaesthesia to $\mathrm{I} \cdot \mathrm{I} \mathrm{ng} / \mathrm{ml}$ after 2 hours of bypass. This fall was due principally to dilution of the plasma volume by the oxygenator prime and by transfusion. The mean concentration on the first postoperative day was $1 \cdot 7 \mathrm{ng} / \mathrm{ml}$. Thus cardiopulmonary bypass does not cause any appreciable increase in digoxin excretion or loss. On the other hand, by temporarily impairing renal function and reducing the plasma concentrations of potassium and magnesium, it tends to reduce maintenance requirements of digoxin.

The management of patients after cardiac operations is frequently hindered by uncertainty regarding the effect of cardiopulmonary bypass on the degree of digitalization. Heart rate in this situation is an unreliable guide even in the presence of atrial fibrillation, and clinicians may be in doubt whether arrhythmias should be treated by withholding or by increasing doses of digoxin. The information concerning the effect of cardiopulmonary bypass on plasma levels of digoxin available until now has depended upon experiments in which small doses of tritiated digoxin have been given to patients before operation. Beall et al. (1963) found that labelled digoxin could be detected in the pump oxygenator after patients had undergone a period of cardiopulmonary bypass, but that whereas small reductions in plasma concentration of digoxin occurred, no fall in myocardial concentration could be measured over the period of operation. Ebert, Morrow, and Austen (1963) conducted similar studies and reported reductions of up to 28 per cent in myocardial digoxin concentrations. However, the design of these experiments did not permit the accumulation of tissue stores of labelled digoxin, and the results may not be applicable to patients on long-term treatment with the drug.

Received 30 June 1970.

1 Present address: Royal Sussex County Hospital, Brighton, Sussex.
The radioimmunoassay for digoxin recently introduced by Smith, Butler, and Haber (1969) provides a specific and accurate method for measuring plasma concentrations of unlabelled digoxin. We have used the technique to investigate the effects of cardiopulmonary bypass on plasma concentrations of the drug in chronically digitalized patients.

\section{Patients and methods}

Eleven patients were studied during and after operation which involved cardiopulmonary bypass. Their ages ranged from 32 to 60 years (mean 5I): 9 had rheumatic heart disease, $I$ an atrial septal defect, and I aortic valve disease which was thought to be congenital. All had been maintained on digoxin for at least 5 years; the daily dose was $0.25 \mathrm{mg}$ in 3 patients, $0.5 \mathrm{mg}$ in 6 , and $0.75 \mathrm{mg}$ in the remaining 2. No digoxin was given for at least 24 hours before operation, and none was given throughout the period of the study. The patients' renal function was normal or near normal as judged by blood urea concentrations of less than $40 \mathrm{mg} / \mathrm{roO} \mathrm{ml}$. Conventional bypass techniques were employed, using Rygg, Baxter, or KayCross oxygenators. The oxygenators were primed with Hartmann's or Plasmolyte solution sometimes supplemented by small volumes of whole blood. The volumes used for the prime and the volumes transfused during operation were noted. During bypass the patients were hypothermic at about $28^{\circ} \mathrm{C}$.

Blood samples were taken for estimation of plasma digoxin concentration on 4 occasions: at the time of induction of anaesthesia, 2 hours after the start of the bypass, 4 hours after completion 
of bypass, and finally on the following day approximately 16 hours after completion of bypass. The blood remaining in the oxygenator at the end of bypass was pooled with blood from the discard sucker. The total volume was measured and an aliquot taken for measurement of digoxin concentration. The total volumes of urine passed before, during, and after cardiopulmonary bypass were measured separately and the digoxin concentrations were estimated.

Plasma digoxin concentrations were measured by radioimmunoassay (Smith et al., 1969; Chamberlain et al., 1970). The method is specific and capable of measuring digoxin concentrations as low as $0.25 \mathrm{ng} / \mathrm{ml}$ ( $\mathrm{I} \mathrm{ng}=\mathrm{IO}^{-9} \mathrm{~g}$ ). Urine digoxin concentrations were also measured by radioimmunoassay using urine dilutions of $I: I 00$ in barbitone buffer containing human serum albumin.

Measurements of creatinine excretion were obtained in 4 patients during and after operation; plasma and urine creatinine concentrations were measured by AutoAnalyser.

The statistical significance of the results was determined by the $t$ test for paired comparisons.

\section{Results}

Changes in plasma digoxin concentrations (Fig. I) At the time of induction of anaesthesia, the plasma digoxin concentration in II patients ranged from 0.3 to $2.5 \mathrm{ng} / \mathrm{ml}$ (mean I.5 \pm S.E.M. 0.3). Plasma samples taken after 2 hours of cardiopulmonary bypass showed a reduction in digoxin levels in 8 patients, no change in 2 , and a trivial rise in $I$ (mean $\mathrm{I} \cdot \mathrm{I} \mathrm{ng} / \mathrm{ml} \pm 0 \cdot 2$ ). The overall reduction in the mean concentration was significant $(P<0.05)$. Only small and inconstant changes had occurred when the next samples were - taken 4 hours after the end of cardiopulmonary bypass, and the mean level was identical - (I.I $\mathrm{ng} / \mathrm{ml} \pm 0.2$ ) (I $\mathrm{ng}=\mathrm{IO}^{-9} \mathrm{~g}$ ). After a further 12 hours, however, plasma digoxin concentration had risen in 8 of the II patients, and the mean was slightly higher than that at induction $(1 \cdot 7 \mathrm{ng} / \mathrm{ml} \pm 0 \cdot 4)$. The increase in concentration which occurred after operation was significant at the 5 per 、 cent level of probability.

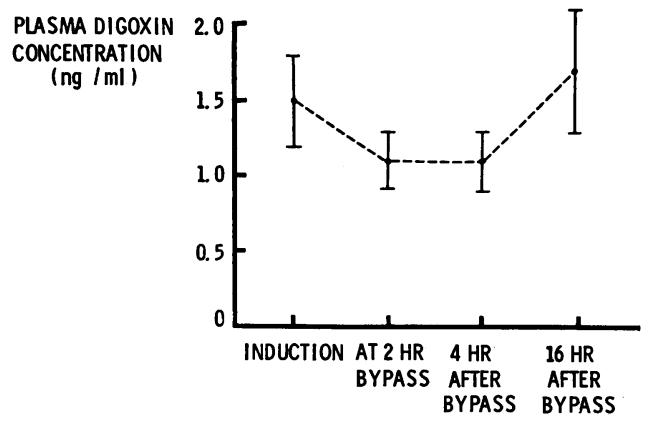

FIG. I Mean plasma digoxin concentrations in II patients before, during, and after cardiopulmonary bypass. The vertical bars represent standard errors of the mean.

Loss of digoxin during operation Complete data were available in 8 of the II patients, and are presented in the Table. In the operative period before the start of cardiopulmonary bypass, the mean rate of urine flow was $67 \mathrm{ml} / \mathrm{hr}$. This increased conspicuously during bypass to $623 \mathrm{ml} / \mathrm{hr}$. However, the increased flow was accompanied by a corresponding reduction in urinary digoxin concentrations (Fig. 2), and little change occurred in the rate of digoxin loss. After bypass had been discontinued the mean rate

FIG. 2 Mean rate of urine flow and mean urine digoxin concentration in 8 patients before, during, and after cardiopulmonary bypass.

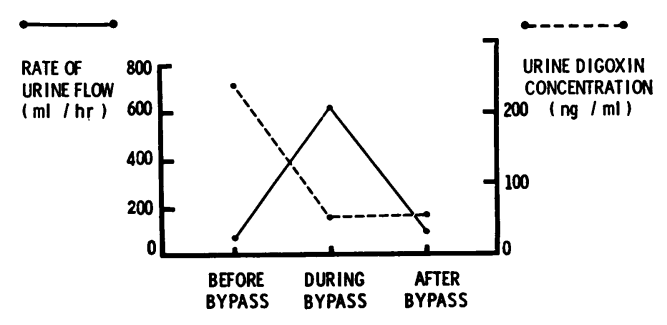

TABLE Total operative digoxin loss (means $\pm S D$ in 8 patients)

\begin{tabular}{|c|c|c|c|c|}
\hline • & Volume $(m l)$ & $\begin{array}{l}\text { Concentration } \\
\text { of digoxin } \\
(n g / m l)\end{array}$ & $\begin{array}{l}\text { Loss of digoxin } \\
(n g)\end{array}$ & $\begin{array}{l}\text { Rate of digoxin } \\
\text { excretion } \\
(n g / h r)\end{array}$ \\
\hline \multicolumn{5}{|l|}{ Urine } \\
\hline (a) Induction to bypass & $173 \pm I 14$ & $243 \pm 157$ & $47,000 \pm 42,700$ & 18,500 \\
\hline (b) During bypass & $1,536 \pm 224$ & $50 \pm 43$ & $71,700 \pm 67,200$ & 29,100 \\
\hline (c) After bypass & $298 \pm 147$ & $53 \pm 50$ & $14,800 \pm 14,000$ & 4,700 \\
\hline Pump reservoir and discard sucker & $2,275 \pm 883$ & $1 \cdot 2 \pm 0 \cdot 7$ & $2,800 \pm 1,800$ & \\
\hline
\end{tabular}

Total operative loss $=136,300 \mathrm{ng}(0.14 \mathrm{mg})$. 
of urine flow decreased but the urinary digoxin concentration remained low. Therefore the mean rate of digoxin excretion fell abruptly at this stage of operation from 484 $\mathrm{ng} / \mathrm{min}$ to only $79 \mathrm{ng} / \mathrm{min}$. In 5 patients, changes in creatinine concentration were compared with the simultaneous changes in digoxin concentration, and the pattern was found to be similar (Fig. 3). The total loss of digoxin from the urinary tract during operation averaged $134,000 \mathrm{ng}$ ( $0.134 \mathrm{mg}$ ).

The amount of digoxin left in the pump prime and in the discard sucker bottle at the end of operation was also measured. This averaged only $2,800 \mathrm{ng}$.

The mean loss of digoxin throughout the whole of the operative period was therefore $0.14 \mathrm{mg}$.

Dilution of plasma volume during operation The plasma volume of the patients was estimated, on the basis of an assumed $40 \mathrm{ml} / \mathrm{kg}$ body weight (Beierwaltes, Johnson, and Solari, 1957), to be $2.4 \pm$ SD 0.5 litres. The volume of Hartmann's solution and plasma or its equivalent which was used to prime the oxygenator averaged $3.0 \pm 0.6$ litres. By the end of the second hour of bypass, when the second plasma samples were taken for digoxin concentration, the patients had also been transfused with $0.8 \pm$ 0.4 litre of plasma or its equivalent. Though the plasma volume at this stage cannot be accurately calculated because of equilibration with other fluid compartments, the average fluid expansion (excluding transfused red cells) was 3.8 litres.

Creatinine clearances After operation, creatinine clearance in 4 patients increased progressively over approximately three days and then stabilized (Fig. 4). The mean value on the first day was $39 \mathrm{ml} / \mathrm{min}$, and on the fifth day $57 \mathrm{ml} / \mathrm{min}(P<0.01)$.

\section{Discussion}

The measurement of plasma digoxin concentration has been shown to be of clinical value (Smith et al., 1969; Grahame-Smith and Everest, 1969; Chamberlain et al., 1970). In chronically digitalized patients with normal renal function, plasma concentrations are related to the daily dose of the drug. The therapeutic range of values determined by radioimmunoassay (Smith et al., 1969; Chamberlain et al., 1970) accords closely with that found after the administration of tritiated digoxin to patients with subsequent direct measurement of radioactivity in serum (Marcus et al., 1966). Though some overlap

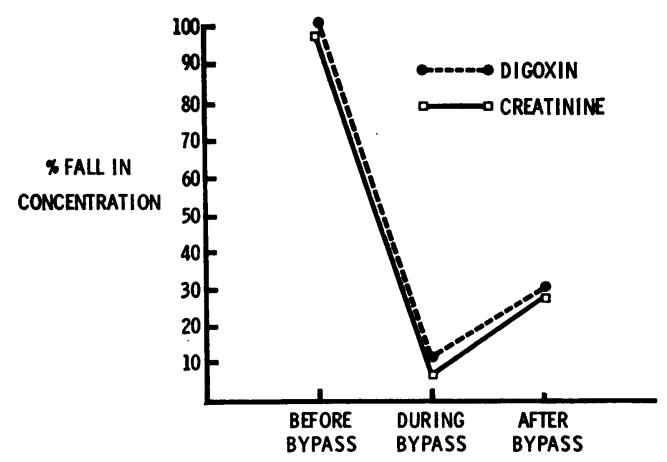

FIG. 3 Percentage change in digoxin and creatinine concentrations in 5 patients during and after cardiopulmonary bypass, the preoperative level being expressed as 100 per cent.

exists between therapeutic and toxic ranges, most patients on maintenance treatment have plasma concentrations of $\mathrm{I}$ to $2 \mathrm{ng} / \mathrm{ml}$, and digoxin toxicity is usually associated with levels greater than $2 \mathrm{ng} / \mathrm{ml}$.

The individual plasma concentrations of digoxin in the present series varied widely at the time of induction of anaesthesia both because the daily dose ranged from 0.25 to $0.75 \mathrm{mg}$ and because of differences in the time for which the drug had been stopped before the day of operation. The mean level fell significantly between the time of induction and the end of the first 2 hours of bypass, from $\mathrm{I} \cdot 5$ to $\mathrm{I} \cdot \mathrm{I} \mathrm{ng} / \mathrm{ml}$. This rate of fall is much greater than would be expected from the known half-life of digoxin in patients with normal renal function. The reduction persisted for at least 4 hours after the completion of bypass but by the following day had risen to $1.7 \mathrm{ng} / \mathrm{ml}$, slightly higher than the concentration before operation. No further digoxin had been administered during this time.

FIG. 4 Mean creatinine clearances in 4 patients for the first five postoperative days. The vertical bars represent standard errors of the mean.

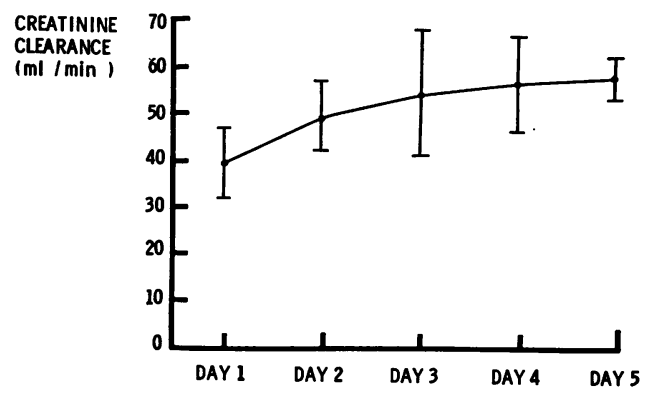


The initial abrupt fall in digoxin concentration must have been due to some combination of loss of the glycoside during the operative period and of dilution of the plasma volume. Both of these variables were examined. Under normal circumstances the urinary tract is the most important route for loss of digoxin, and more than 80 per cent is excreted unchanged by the kidneys (Doherty and Perkins, 1962). The rate of urinary flow increased conspicuously when the patients went on to bypass, but at the same time a fivefold reduction in mean urine digoxin concentration occurred; the overall rate of digoxin excretion therefore showed only a modest increment. Furthermore, in the longer period after the end of bypass both urine flow and concentration were low, and therefore the rate of digoxin excretion fell off sharply. The total loss of digoxin from the urinary tract throughout the whole operation (mean of 8 hours) averaged $0.134 \mathrm{mg}$. Digoxin left in the oxygenator and the discard sucker bottle at the end of bypass added no more than $0.003 \mathrm{mg}$. Judging from - the maintenance requirements of our 8 patients in whom excretion data are available, the mean urinary loss in a similar period without operation would be approximately $0.15 \mathrm{mg}$. Precise comparisons cannot be made, but clearly the rate of loss of digoxin during operation did not differ to any important degree from the usual rate of loss.

The rapid fall in plasma concentration of digoxin during and after cardiopulmonary bypass, which was not due to loss of the drug, can readily be explained by dilution. The estimated average plasma volume of our patients was 2.4 litres. No less than 3.8 litres were added by transfusion and from the oxygenator prime by the time the second plasma samples were taken. No estimate can be made of the expansion of the plasma volume at the time of sampling because of the unknown distribution of fluid between the different compartments and because of the profuse diuresis. If it were not for these factors and for re-equilibration between - plasma and tissue stores of digoxin, the plasma concentration would have fallen to a much lower level than the observed figure of $\mathbf{I} \cdot \mathbf{I} \mathrm{ng} / \mathrm{ml}$.

The greatest tissue stores of digoxin are in skeletal muscle. The concentrations are much - less than in some other tissues such as kidneys, myocardium, and liver; but the bulk of -skeletal muscle, which may comprise up to 43 per cent of body weight (Grant, I958), ensures that it provides the largest reservoir. Doherty, Perkins, and Flanigan (1967) found in acute experiments that muscle concentra- tions of tritiated digoxin were on an average nearly five times greater than those in serum; our own preliminary data (unpublished) using radioimmunoassay suggest that the ratio is even higher in chronically digitalized patients. These large tissue stores not only limit any tendency for an acute fall in plasma concentration but also readily allow a restoration of plasma level as re-equilibration occurs. Tissue damage during operation evidenced by rises in myocardial and skeletal muscle enzymes may also aid the postoperative rebound in plasma concentrations of digoxin. A further factor in re-equilibration after operation must be a return towards normal of the expanded plasma volume.

Not only does cardiopulmonary bypass not cause any important increase in the rate of digoxin loss, it is actually accompanied by several factors which increase sensitivity to digoxin and also temporarily reduce the rate of excretion of the drug postoperatively. Lockey et al. (1966) showed that cardiopulmonary bypass resulted in large urinary losses of potassium and that plasma levels fell postoperatively despite supplements. The effect of cardiac glycosides is thereby enhanced (Sampson, Alberton, and Kondo, 1943). Plasma magnesium is also reduced after bypass operation (Scheinman, Sullivan, and Hyatt, 1969), and this further increases the sensitivity of the myocardium to digoxin (Seller et al., 1970). The clearance of digoxin from the kidneys depends upon glomerular filtration rate (Bloom, Nelp, and Tuell, 1966). Though we did not measure digoxin clearance postoperatively, the creatinine clearances (Fig. 4) show that glomerular filtration recovers only slowly after operation; so that for several days maintenance requirements of the drug will be somewhat reduced.

Our data confirm that the loss of digoxin into the residual volume of the oxygenator prime is trivial because the blood carries only a small proportion of the total digoxin store. Furthermore, cardiopulmonary bypass does not increase urinary excretion of the drug. Bypass does, however, have metabolic consequences which increase sensitivity to cardiac glycosides, and also cause temporary changes in renal function, which reduce maintenance requirements. Caution is, therefore, necessary in the administration of digoxin postoperatively to patients who have been chronically and adequately digitalized before operation.

We are grateful to Mr. O. S. Tubbs and Mr. I. M. Hill for permission to study patients under their care, to Dr. Edgar Haber and Dr. John Hamer for encouragement and help, and to the nursing staff 
for their invaluable co-operation. Dr. D. J. Coltart is in receipt of a research grant from Imperial Chemical Industries Ltd. and is the Mary Scharlieb Research Scholar of the University of London and the Cooper and Coventson Research Scholar of St. Bartholomew's Hospital 1970/71.

\section{References}

Beall, A. C., Johnson, P. C., Driscoll, T., Alexander, J. K., Dennis, E. W., McNamara, D. G., Cooley, D. A., and DeBakey, M. E. (1963). Effect of total cardiopulmonary bypass on myocardial and blood digoxin concentration in man. American fournal of Cardiology, II, 194.

Beierwaltes, W. H., Johnson, P. C., and Solari, A. J. (1957). Clinical Use of Radioisotopes, p. 197. W. B. Saunders, Philadelphia.

Bloom, P. M., Nelp, W. B., and Tuell, S. H. (I966). Relationship of the excretion of tritiated digoxin to renal function. American fournal of the Medical Sciences, 251, 133.

Chamberlain, D. A., White, R. J., Howard, M. R., and Smith, T. W. (1970). Plasma digoxin concentrations in patients with atrial fibrillation. British Medical fournal, 3, 429.

Doherty, J. E., and Perkins, W. H. (1962). Studies with tritiated digoxin in human subjects after intravenous administration. American Heart fournal, $63,528$.

Doherty, J. E., Perkins, W. H., and Flanigan, W. J. (1967). The distribution and concentration of tritiated digoxin in human tissues. Annals of Internal Medicine, 66, 116.

Ebert, P. A., Morrow, A. G., and Austen, W. G. (I963). Clinical studies of the effect of extracorporal circulation on myocardial digoxin concentration. American fournal of Cardiology, 11, 201.

Grahame-Smith, D. G., and Everest, M. S. (1969). Measurement of digoxin in plasma and its use in diagnosis of digoxin intoxication. British Medical fournal, r, 286.
Grant, J. C. B. (1958). A Method of Anatomy, 6th ed., p. 7. Williams and Wilkin, Baltimore.

Lockey, E., Longmore, D. B., Ross, D. N., and Sturridge, M. F. (I966). Potassium and openheart surgery. Lancet, I, 67I.

Marcus, F. I., Burkmalter, L., Cuccia, C., Pavlovich, J., and Kapadia, G. G. (I966). Administration of tritiated digoxin with and without a loading dose: a metabolic study. Circulation, 34, 865 .

Sampson, J. J., Alberton, E. C., and Kondo, B. (1943). The effect on man of potassium administration in relation to digitalis glycosides, with special reference to blood serum potassium, the electrocardiogram, and ectopic beats. American Heart fournal, 26, 164.

Scheinman, M. M., Sullivan, R. W., and Hyatt, K. H. (1969). Magnesium metabolism in patients undergoing cardiopulmonary bypass. Circulation, 39, Suppl. I, p. 235.

Seller, R. H., Cangiano, J., Kim, K. E., Mendelssohn, S., Brest, A. N., and Swartz, C. (1970). Digitalis toxicity and hypomagnesemia. American Heart Fournal, 79, 57.

Smith, T. W., Butler, V. P., and Haber, E. (1969). Determination of therapeutic and toxic serum digoxin concentrations by radioimmunoassay. New England fournal of Medicine, 281, 1212.

\section{Addendum}

Since submission of this papera similar study has been reported (Morrison, Killip, and Stason, I970).

\section{Reference}

Morrison, J., Killip, T., and Stason, W.B. (1970). Serum digoxin levels in patients undergoing cardiopulmonary bypass. Circulation, 41, Suppl. 3, p. IIO. 